\title{
ANALYTICAL CALCULATION OF DEFLECTION OF A MULTI-LATTICE TRUSS WITH AN ARBITRARY NUMBER OF PANELS
}

\author{
Mikhail N. Kirsanov \\ National research University "MPEI", \\ Moscow, RUSSIA
}

\begin{abstract}
The scheme of a planar externally statically indeterminate truss with four supports is proposed. In analytical form, for several types of loads, the problem of forces in the rods and deflection of the structure is solved, depending on the number of panels, the size and intensity of the load. The solution uses the Maple computer mathematics system. The deflection at Midspan is determined using Maxwell - Mohr's formula, the forces in the rods - the method of cutting out nodes from the system of equilibrium equations for all nodes, which includes four reactions of the supports. By induction, a series of solutions for trusses with a consistently increasing number of panels is generalized to an arbitrary number of panels. For the elements of the sequences of coefficients are developed and are solved by homogeneous linear recurrence equations. The resulting formulas for the deflection of the structure under various loads have the form of polynomials in the number of panels. A linear asymptotic solution for the number of panels is found. The kinematic degeneration of the structure and the distribution of node speeds corresponding to this case were found. The dependences of the reaction of supports and forces in the most compressed and stretched rods on the number of panels are determined.
\end{abstract}

Keywords: truss, deflection, induction, Mohrs' integral, Maple, kinematic degeneration

\section{АНАЛИТИЧЕСКИЙ РАСЧЕТ ПРОГИБА МНОГОРЕШЕТЧАТОЙ ФЕРМЫ С ПРОИЗВОЛЬНЫМ ЧИСЛОМ ПАНЕЛЕЙ}

\author{
М.Н. Кирсанов \\ Национальный исследовательский университет "Московский энергетический \\ институт",Москва, РОССИЯ
}

\begin{abstract}
Аннотация: Предлагается схема плоской внешне статически неопределимой фермы с четырьмя опорами. В аналитической форме для нескольких видов нагрузок решается задача об усилиях в стержнях и прогибе конструкции в зависимости от числа панелей, размеров и интенсивности нагрузки. Для решения используется система компьютерной математики Maple. Прогиб в середине пролета определяется по формуле Максвелла - Мора, усилия в стержнях - методом вырезания узлов из системы уравнений равновесия всех узлов, в которую включаются и четыре реакции опор. Методом индукции серия решений для ферм с последовательно увеличивающимся числом панелей обобщается на произвольное число панелей. Для элементов последовательностей коэффициентов составляются и решаются однородные линейные рекуррентные уравнения. Полученные формулы для прогиба конструкции при различных нагружениях имеют вид полиномов по числу панелей. Найдена линейная асимптотика решения по числу панелей. Обнаружено кинематическое вырождение конструкции и распределение скоростей узлов, соответствующее этому случаю. Определены зависимости реакций опор и усилий в наиболее сжатых и растянутых стержнях от числа панелей.
\end{abstract}

Ключевые слова: ферма, прогиб, индукция, интеграл Мора, Марle, кинематическое вырождение

\section{INTRODUCTION}

The calculation of rod structures is usually performed in numerical packages based on the finite element method [1-4]. The usual solution of the mechanics problem, performed not in a numerical package, but in a system of symbolic mathematics, without changing the basic equations and calculation scheme, gives an analytical solution to the problem in the form of a formula. In the years when computer mathematics systems first appeared, this caused the optimism of calculators who know the importance of analytical solutions. However, 
almost immediately, many on this path encountered two obstacles. First, most of the resulting formulas were so complex that it was not only impossible to use them, but even difficult to view them, since their listing took up several pages. The second disadvantage of the solutions obtained in this way is that the range of applicability of the obtained formulas (if they are obtained in a relatively compact form) is usually not wide. Among the parameters of formulas, you can easily enter the size of the calculated object, elastic or rheological properties of the material, and the intensity of a certain load. In order to use a formula with a different number of structural elements, such as rods or panels, if you are talking about trusses, you must output a formula that is intended for this number. If overcoming the first disadvantage of analytical solutions associated with their bulkiness is possible with some skill in working with simplification operators included in computer mathematics systems, the second disadvantage can be overcome using the induction method [5]. The induction method is applicable for regular constructions that have periodicity cells of the structure. Solutions are known for a number of planar [6-13] and spatial [14] statically definable trusses. The significance of regular statically definable schemes was first evaluated by Hutchinson R. G., Fleck N. A., Zok F. W., Latture R. M., Begley M. R. [15-17]. Monographs [18,19] are devoted to such schemes and methods of their calculation. The reference book [20] contains more than 70 schemes of planar trusses and formulas for calculating deflection and forces in rods critical to stability and strength. Tinkov D.V. [21] and Osadchenko N.V. [22] provides an overviews of some analytical solutions for planar trusses.

\section{MATERIALS AND METHODS}

The geometry of the truss. The case of variability of the design

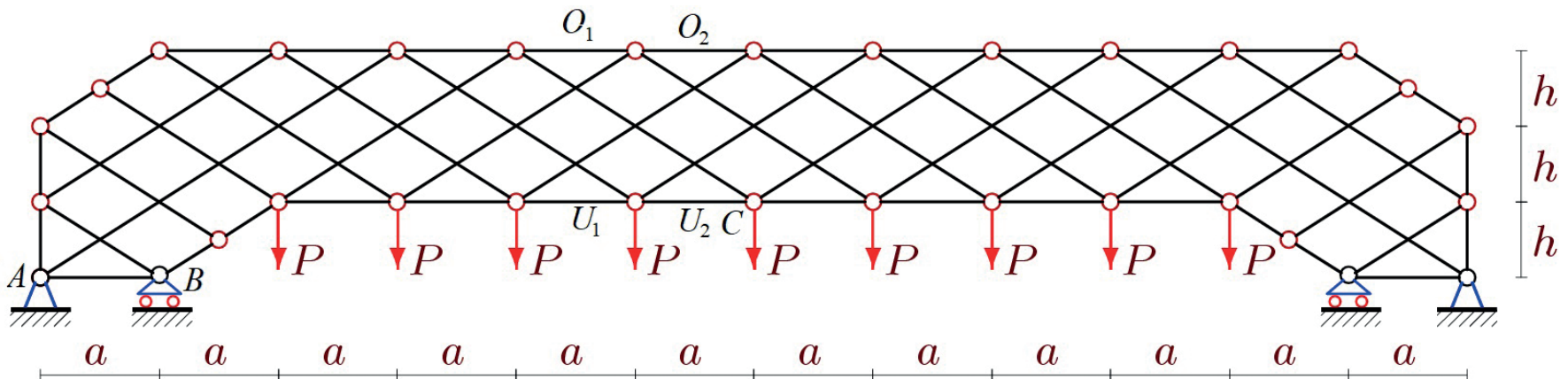

Figure 1. The load on the bottom belt, $n=5$
Let's consider a symmetrical lattice truss of beam type with $2 \mathrm{n}$ panels, counting the elements of the upper belt with length a (Fig. 1). In its middle part, the lower belt is slightly raised. Due to the four supports, the truss is externally statically indeterminate. The reactions of the supports of such a truss can only be calculated from the joint solution of the system of equilibrium equations of all nodes simultaneously with the forces in the rods. The truss contains $m=$ $8 n+24$ rods, including six rods that model movable and fixed supports.

We will calculate the forces in the rods using the program [6-13], compiled in the language of the Maple system, which is close to the Pascal language. The program includes the coordinates of the joints and the structure of the connection of the rods. The matrix of a system of equations consists of the guiding cosines of forces. The vector of the right part of the system of equilibrium equations includes loads on nodes. At the same time, in the first test calculations, it was noticed that for trusses with an even number of panels $n$ in half the span, the matrix determinant degenerates, which indicates the instantaneous variability of the system $[20,23]$. Note that calculations in numerical form hid the fact that the determinant turned to zero for the error of the calculation, and only analytical (or integer) calculation clearly gave out this dangerous feature of the construction under consideration. A picture of the distribution of possible velocities of nodes is obtained (Fig. 2), confirming the kinematic variability of the truss.

The following velocity ratios are obtained from considering the positions of the instantaneous velocity centers of individual rods: $u^{\prime} / h=v / a, 2 u / c=$ $v / a$ where $c=\sqrt{a^{2}+h^{2}}$. Most of the truss joints and supports remain stationary. 


\section{RESULTS}

\section{The Forces In The Rods}

The distribution of forces in the truss rods at $a=4$ $\mathrm{m}, h=3 \mathrm{~m}$ from the action of the load applied to the nodes of the lower belt, obtained from the numerical calculation data (Fig. 3), shows that the upper belt is partially compressed, the lower one is stretched in its central part . Compressed elements are highlighted in blue, stretched elements in red, and unloaded ones in black. The thickness of the lines is proportional to the modulus of force. The efforts are related to the value of force $P$. With an increase in the number of panels, the stretched zone in the lower zone naturally expands. It should be noted that the most compressed rods are not in the middle of the span. Using the induction method, one can obtain analytical expressions of the reactions of supports and forces in some rods of the truss (marked in Fig. 1). We have the following expressions for the reactions of supports:

$$
\begin{gathered}
Y_{A}=2 P(k-1), Y_{B}=P / 2, \\
X_{A}=P(4 k-3) a /(2 h) .
\end{gathered}
$$

Forces in the middle of the upper belt:

$$
\begin{aligned}
& O_{1}=-P\left(4 k^{2}-2 k(-1)^{k}-4 k+(-1)^{k}-1\right) a /(4 h), \\
& O_{2}=-P\left(4 k^{2}+2 k(-1)^{k}-4 k+(-1)^{k}+1\right) a /(4 h) .
\end{aligned}
$$

Forces in the lower belt:

$$
\begin{aligned}
& U_{1}=P\left(4 k^{2}+2 k(-1)^{k}-12 k-(-1)^{k}+1\right) a /(4 h), \\
& U_{2}=P\left(4 k^{2}-2 k(-1)^{k}-12 k-(-1)^{k}+3\right) a /(4 h)
\end{aligned}
$$

\section{Deflection}

Truss deflection (vertical displacement of the middle node $C$ from the lower belt) it is determined by the Maxwell-Mohr's formula $\Delta=\sum_{i-1}^{m-6} S_{i}^{(P)} S_{i}^{(\mathrm{l})} l_{i} /(E F)$, where the sum is calculated only for deformable truss rods. It is indicated: $S_{i}^{(1)}$ - forces from the unit force applied to the lower belt, $S_{i}^{(P)}$ - forces in the rods from a given load, $l_{i}$ - the length of the rods, $E F$ their stiffness.

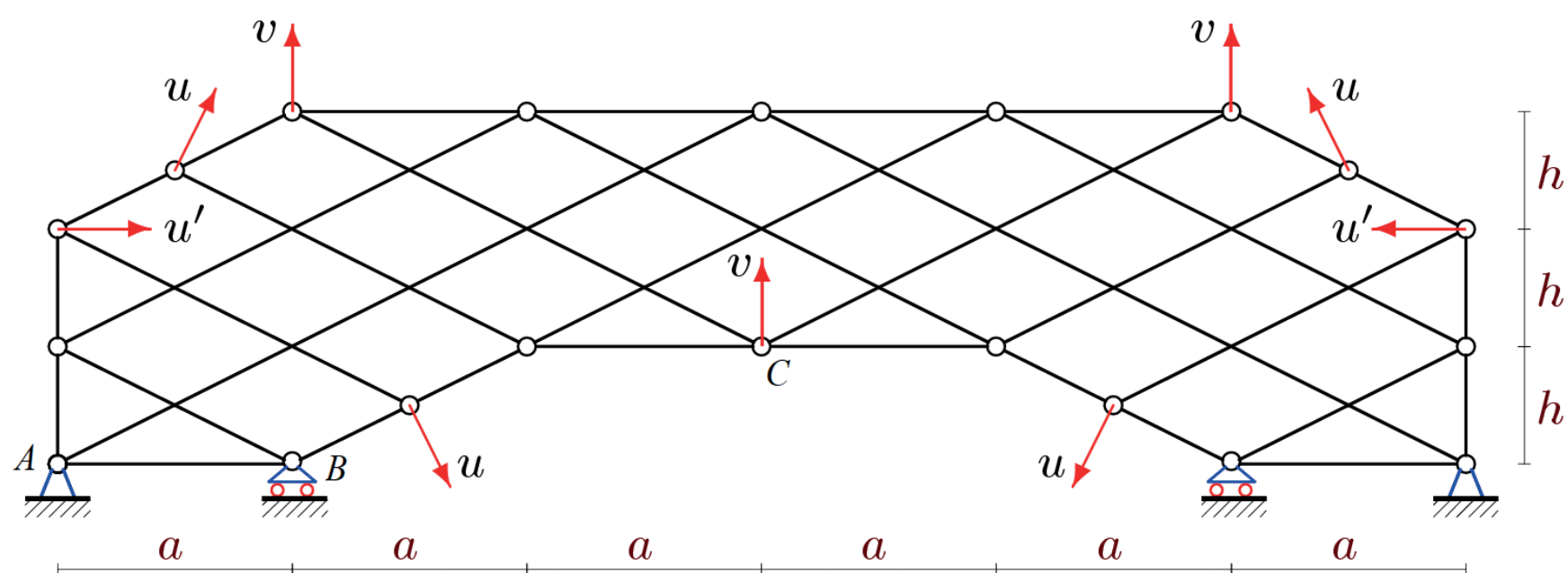

Figure 2. Velocities distribution of an instantaneous variable truss, $n=2$

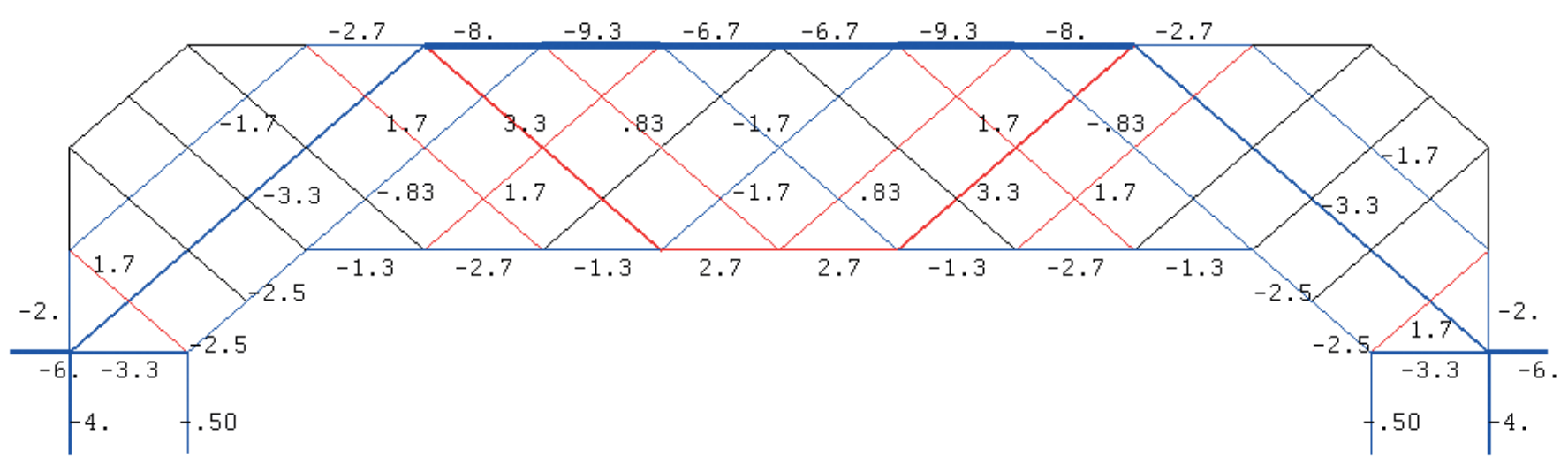

Figure 3. The distribution of forces in the truss, $n=5$ 


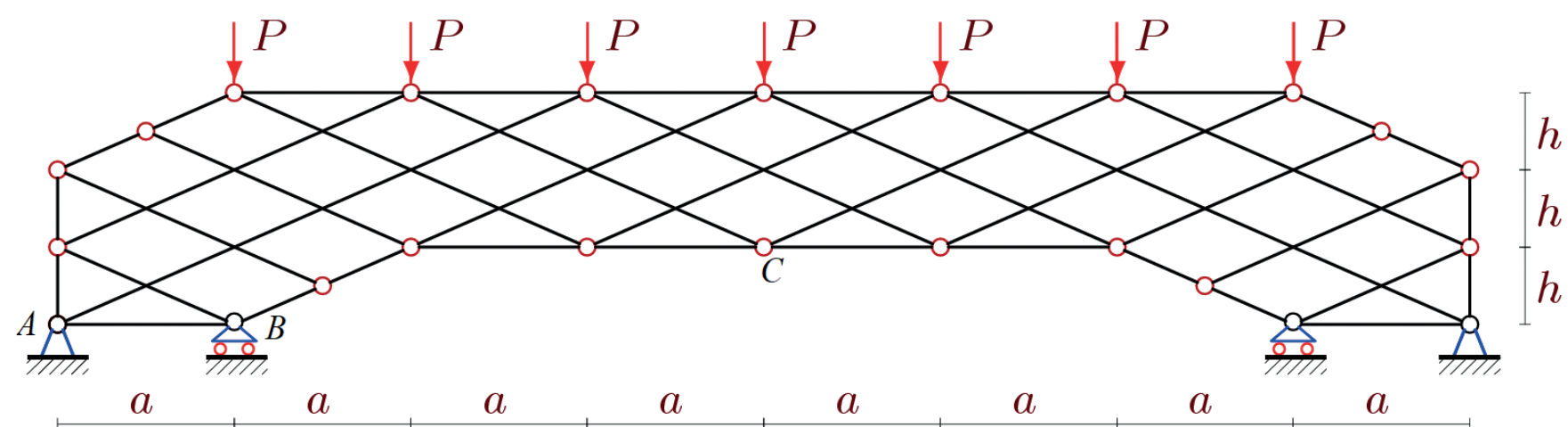

Figure 4. The load on the upper belt, $n=3$

Let's consider the case of a uniform load on the nodes of the upper belt (Fig. 1). Regardless of the number of panels, the deflection has the form:

$$
\Delta=P\left(C_{1} a^{3}+C_{2} c^{3}+C_{3} h^{3}\right) /\left(h^{2} E F\right) .
$$

Coefficients for size degrees depend only on the number of panels. We consider odd numbers for which the determinant of the system of linear equations of equilibrium of nodes does not turn to zero. To determine these dependencies, you need to calculate a number of trusses with a consistently increasing number of panels and find common members of the sequences. To determine the coefficient $C_{1}$, it was necessary to calculate 18 trusses with the number $\mathrm{k}=1, \ldots, 18$ and get the sequence $1 / 2,19 / 2,53 / 2$, $383 / 2, \ldots, 292115 / 2$.

First the rgf_findrecur operator returns a linear homogeneous recurrent equation for elements in the sequence:

$$
\begin{gathered}
C_{1, k}=C_{1, k-1}+4 C_{1, k-2}-4 C_{1, k-3}-6 C_{1, k-4}+ \\
+6 C_{1, k-5}+4 C_{1, k-6}-4 C_{1, k-7}-C_{1, k-8}+C_{1, k-9} .
\end{gathered}
$$

Then the General term of this sequence, as a solution of the recurrent equation, gives the rsolve operator:

$$
\begin{gathered}
C_{1}=\left(20 k^{4}+16 k^{3}(-1)^{k}-80 k^{3}-48 k^{2}(-1)^{k}+\right. \\
\left.+130 k^{2}+50 k(-1)^{k}-58 k-9(-1)^{k}+3\right) / 12 .
\end{gathered}
$$

Other coefficients are obtained in the same way:

$$
\begin{gathered}
C_{2}=\left(k^{2}+k(-1)^{k}-(-1)^{k}\right) / 2 \\
C_{3}=(k-1)\left(1+(-1)^{k}\right) .
\end{gathered}
$$

Expression (1) with the found dependencies $C_{i}=$ $C_{i}(k), i=1,2,3$ is the solution to the problem.

The used algorithm for output of calculation formulas can be easily adjusted to other loads. Consider the load on the upper belt of the truss (Fig. 4).
The coefficients in (1) in this case have the form:

$$
\begin{gathered}
C_{1}=\left(20 k^{4}+16 k^{3}(-1)^{k}-80 k^{3}-48 k^{2}(-1)^{k}+\right. \\
\left.+130 k^{2}+50 k(-1)^{k}-70 k-15(-1)^{k}+9\right) / 12, \\
C_{2}=k\left(k+(-1)^{k}\right) / 2, \\
C_{3}=k\left(1+(-1)^{k}\right) .
\end{gathered}
$$

In the case of loading the truss with a single force applied to the hinge $\mathrm{C}$ in the middle of the lower belt, the problem is solved somewhat easier. The coefficients in expression (1) have a lower degree:

$$
\begin{gathered}
C_{1}=\left(4 k^{3}+6 k^{2}(-1)^{k}-12 k^{2}-12 k(-1)^{k}+\right. \\
\left.+20 k+9(-1)^{k}-6\right) / 6, \\
C_{2}=k+(-1)^{k} / 2, \\
C_{3}=1+(-1)^{k} .
\end{gathered}
$$

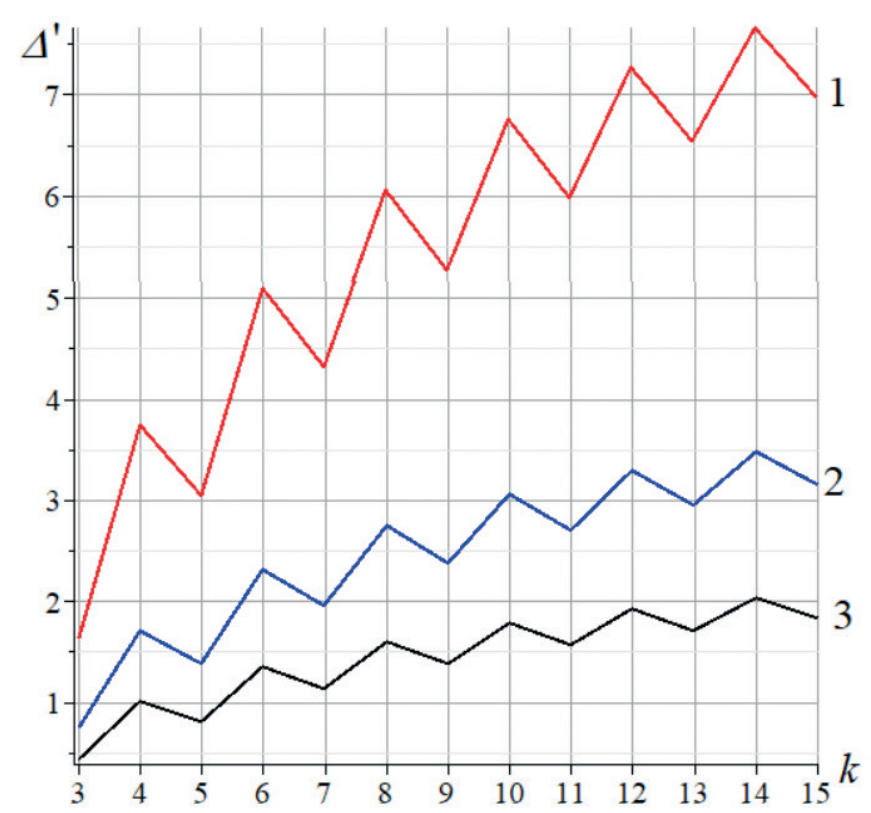

Figure 5. Dependence of the deflection on the number of panels

$$
1-h=2 m, 2-h=3 m, 3-h=3 m
$$


The proposed truss scheme has a number of features that are most conveniently traced by example. Consider a truss of a given length $L=2(n+1) a$ loaded in the lower zone. We also fix the total load on the truss: $P_{\text {sum }}=(2 n-1) P$. We introduce the dimensionless relative deflection: $\Delta^{\prime}=\Delta E F /\left(P_{\text {sum }} \cdot L\right)$. Figure 5 at $L=80 \mathrm{~m}$ shows the dependence of the deflection on the number of panels at various values of the height of the truss. Dependencies have a pronounced spasmodic character. The jumps are especially large at low altitudes and small numbers $k$. As $k$ increases, the curves smooth out, tending to some oblique asymptote. Using Maple, the slope can be calculated:

$$
\lim _{n \rightarrow \infty} \Delta^{\prime} / k=h /(8 L) \text {. }
$$

The angle of inclination is positive, therefore, with an increase in the number of panels with a simultaneous decrease in their length, due to the accepted assumption that the total length of the truss is constant, the relative deflection increases on average (including jumps).

\section{CONCLUSIONS}

Two main conclusions can be drawn. First, the analytical solution for the proposed truss scheme has a simple form. it is valid for an arbitrary number of panels, including a very large number, i.e. precisely in cases when numerical methods can accumulate rounding errors and require significant counting time. Second, the discovery of an unexpected case of kinematic variability should serve as a warning for designers of new schemes, where the degeneracy of the determinant of the system of equations of equality may be hidden behind rounding of intermediate data. Noticeable jumps in the deflection dependence on the number of panels are the basis for optimal selection of the number of panels. Reducing or increasing the number of panels by one can change the stiffness from $10 \%$ to $100 \%$ depending on the number of panels. The linear combination of solutions obtained for three types of loads allows us to solve a wide range of problems for truss of the considered type in analytical form.

\section{REFERENCES}

1. Mathieson C., Roy K., Clifton G., Ahmadi A., Lim J.B.P. Failure mechanism and bearing capacity of cold-formed steel trusses with HRC connectors. Engineering Structures, 2019, Vol. 201, pp. 109741. DOI: 10.1016/j. engstruct.2019.109741

2. Villegas L., Moran R., Garcia J.J. Combined culm-slat Guadua bamboo trusses. Engineering Structures, 2019, 184, pp. 495-504. DOI: 10.1016/j.engstruct.2019.01.114

3. Dong L. Mechanical responses of snap-fit Ti-6Al$4 \mathrm{~V}$ warren-truss lattice structures. International Journal of Mechanical Sciences, 2020, 173, pp. 105460. DOI: 10.1016/j.ijmecsci.2020.105460

4. Vatin N.I., Havula J., Martikainen L., Sinelnikov A.S., Orlova A.V., Salamakhin S.V. Thinwalled cross-sections and their joints: tests and femmodelling. Advanced Materials Research, 2014; 945-949, pp. 1211-1215. DOI: 10.4028/www.scientific.net/AMR.945-949.1211

5. Kirsanov M.N. An inductive method of calculation of the deflection of the truss regular type // Architecture and Engineering. 2016, Vol. 1. No.3. pp. 14-17.

6. Bolotina T.D. The deflection of the flat arch truss with a triangular lattice depending on the number of panels // Bulletin of Scientific Conferences, 2016, No. 4-3(8). pp.7-8. http://vuz.exponenta. $\mathrm{ru} / \mathrm{PDF} / \mathrm{NAUKA} / \mathrm{blt} . \mathrm{pdf}$

7. Kazmiruk I.Yu. On the arch truss deformation under the action of lateral load // Science Almanac, 2016, No. 3-3(17). pp. 75-78.

8. Voropay R.A., Domanov E.V. The dependence of the deflection of a planar beam truss with a complex lattice on the number of panels in the system Maple // Postulat, 2019, No.1. pp. 12

9. Rakhmatulina A.R., Smirnova A.A. The formula for the deflection of a truss loaded at half-span by a uniform load // Postulat, 2018, No. 3(29), pp. 22

10. Rakhmatulina A.R., Smirnova A.A. Analytical calculation and analysis of planar springel truss // Structural mechanics and structures, 2018, No.2 (17), pp. 72-79.

11. Rakhmatulina A.R., Smirnova A.A. The dependence of the deflection of the arched truss 
loaded on the upper belt, on the number of panels // Science Almanac, 2017, No. 2-3(28), pp. 268-271. http://vuz.exponenta.ru/PDF/NAUKA/ RahmSmirn.pdf

12. Ilyushin A.S. The formula for calculating the deflection of a compound externally statically indeterminate frame. Structural mechanics and structures, 2019, Vol. 3, No. 22, pp. 29-38. http:// vuz.exponenta.ru/PDF/NAUKA/Ilushin2019.pdf

13. Domanov E.V. The dependence of the deflection of the cantilever truss on the number of panels obtained in the system Maple // Structural mechanics and structures, 2018, Vol.2, No.17, pp. 80-86. http://vuz.exponenta.ru/PDF/NAUKA/ Domanov2018-2.pdf

14. Kirsanov M.N. Analiticheskoye issledovaniye zhestkosti prostranstvennoy staticheski opredelimoy fermy [Analytical study on the rigidity of statically determinate spatial truss]. Vestnik MGSU, 2017, Vol. 12, No. 2 (101), pp. 165-171. (in Russian).

15. Hutchinson R. G., Fleck N.A. Microarchitectured cellular solids the hunt for statically determinate periodic trusses. Zeitschrift für Angewandte Mathematik und Mechanik, 2005, 85(9), pp. 607-617.

16. Hutchinson R.G., Fleck N.A. The structural performance of the periodic truss. Journal of the Mechanics and Physics of Solids. 2006; 54(4). pp. 756-782.

17. Zok F.W., Latture R.M., Begley M.R. Periodic truss structures. Journal of the Mechanics and Physics of Solids, 2016, 96, pp. 184-203.

18. Ignatiev V.A. Raschet regulyarnykh sterzhnevykh sistem [Calculation of regular core systems]. Saratov: Saratov Higher Military Chemical Military School, 1973. 433 pages. (in Russian).

19. Galishnikova V.V., Ignatiev V.A. Regulyarnyye sterzhnevyye sistemy. Teoriya i metody rascheta [Regular core systems. Theory and calculation methods]. Volgograd: VolgGASU, 2006, 551 pages. (in Russian).

20. Kirsanov M.N. Planar Trusses: Schemes and Formulas. Cambridge Scholars Publishing. 2019, Lady Stephenson Library, Newcastle upon Tyne, NE6 2PA, UK ISBN (13): 978-1-5275-3531-2. 198 pages.

21. Tinkov D.V. Analiz tochnykh resheniy progiba regulyarnykh sharnirno-sterzhnevykh kon- struktsiy [Analysis of exact solutions for deflection of regular articulated-rod structures]. Structural Mechanics of Engineering Structures and Structures, 2015, No. 6. pp. 21-28. (in Russian).

22. Osadchenko N.V. Analiticheskiye resheniya zadach o progibe ploskikh ferm arochnogo tipa [Analytical solutions to the problems of deflection of flat trusses of arch] type] Structural mechanics and structures, 2018, No. 1(16), pp. 12-33. (in Russian).

23. Kirsanov M.N. Staticheskiy i kinematicheskiy analiz ploskoy fermy regulyarnogo tipa [Static and kinematic analysis of a regular-type flat truss]. Structural mechanics and structures. 2019, No.2(21), pp. 7-19. (in Russian).

\section{СПИСОК ЛИТЕРАТУРЫ}

1. Mathieson C., Roy K., Clifton G., Ahmadi A., Lim J.B.P. Failure mechanism and bearing capacity of cold-formed steel trusses with HRC connectors // Engineering Structures, 2019, pp. 201.

2. Villegas L., Moran R., Garcia J.J. Combined culm-slat Guadua bamboo trusses // Engineering Structures, 2019, 184, pp. 495-504.

3. Dong L. Mechanical responses of snap-fit Ti-6A1$4 \mathrm{~V}$ warren-truss lattice structures // International Journal of Mechanical Sciences, 2020, 173, pp. 105460 .

4. Vatin N.I., Havula J., Martikainen L., Sinelnikov A.S., Orlova A.V., Salamakhin S.V. Thinwalled cross-sections and their joints: tests and femmodelling // Advanced Materials Researc, 2014, pp. 945-949.

5. Kirsanov M.N. An inductive method of calculation of the deflection of the truss regular type // Architecture and Engineering. 2016, Vol. 1. № 3, pp. 14-17.

6. Bolotina T.D. The deflection of the flat arch truss with a triangular lattice depending on the number of panels // Bulletin of Scientific Conferences, 2016, № 4-3(8), pp.7-8.

7. Kazmiruk I.Yu. On the arch truss deformation under the action of lateral load // Science Almanac, 2016, No. 3-3(17), pp. 75-78.

8. Voropay R.A., Domanov E.V. The dependence of the deflection of a planar beam truss with a 
complex lattice on the number of panels in the system Maple // Postulat, 2019, № 1, pp. 12.

9. Rakhmatulina A.R., Smirnova A.A. The formula for the deflection of a truss loaded at half-span by a uniform load // Postulat, 2018, №. $3(29)$, c. 22.

10. Rakhmatulina A.R., Smirnova A.A. Analytical calculation and analysis of planar springel truss // Structural mechanics and structures, 2018, № 2 (17), c. 72-79.

11. Rakhmatulina A.R., Smirnova A.A. The dependence of the deflection of the arched truss loaded on the upper belt, on the number of panels // Science Almanac, 2017, № 2-3(28), c. $268-271$.

12. Ilyushin A.S. The formula for calculating the deflection of a compound externally statically indeterminate frame. Structural mechanics and structure,. 2019, Vol. 3, №. 22, pp. 29-38

13. Domanov E.V. The dependence of the deflection of the cantilever truss on the number of panels obtained in the system Maple // Structural mechanics and structures, 2018, T.2. №17, c. 80-86.

14. Кирсанов М.Н. Аналитическое исследование жесткости пространственной статически определимой фермы // Вестник МГС,. 2017, T. 12. № 2 (101), с. 165-171.

15. Hutchinson R.G., Fleck N.A. Microarchitectured cellular solids - the hunt for statically determinate periodic trusses // Zeitschrift für Angewandte Mathematik und Mechanik, 2005, 85(9), pp. 607-617.
16. Hutchinson R.G., Fleck N.A. The structural performance of the periodic truss // Journal of the Mechanics and Physics of Solids, 2006, 54(4), pp. 756-782.

17. Zok F.W., Latture R.M., Begley M.R. Periodic truss structures // Journal of the Mechanics and Physics of Solids, 2016, 96, pp. 184-203.

18. Игнатьев В.А. Расчет регулярных стержневых систем. Саратов: Саратовское высшее военно-химическое военное училище, 1973. $433 \mathrm{c}$.

19. Галишникова В.В., Игнатьев В.А. Регулярные стержневые системы. Теория и методы расчета. Волгоград: ВолгГАСУ, 2006. 551 с.

20. Kirsanov M.N. Planar Trusses: Schemes and Formulas. Cambridge Scholars Publishing. 2019. Lady Stephenson Library, Newcastle upon Tyne.

21. Тиньков Д.В. Анализ точных решений прогиба регулярных шарнирно-стержневых конструкций // Строительная механика инженерных конструкций и сооружений, 2015, № 6, c. 21-28.

22. Осадченко Н.В. Аналитические решения задач о прогибе плоских ферм арочного типа // Строительная механика и конструкции, 2018, T. 1. № 16, с. 12-33.

23. Кирсанов М.Н. Статический и кинематический анализ плоской фермы регулярного типа // Строительная механика и конструкции, 2019, №2(21), с. 7-19.

Mikhail N. Kirsanov, Professor, doctor of physico-mathematical Sciences, National Research University "MPEI", Department of Robotics, Mechatronics, Dynamics and Machine Strength; 111250, Russia, Moscow, Krasnokazarmennaya str., 14; tel. +7(495)362-73-14, e-mail: c216@ya.ru

Кирсанов Михаил Николаевич, профессор, доктор физико-математических наук, Национальный исследовательский университет "МЭИ", кафедра робототехники, мехатроники, динамики и прочности машин; 111250, Россия, г. Москва, ул. Красноказарменная, дом 14; тел.+7(495)362-73-14, e-mail: c216@уа.ru 